\title{
Some Forensic Aspects on Drug Analysis and Their Quantity in Autopsy Material of Drug Related Deaths
}

\author{
Vinod Dhingra* \\ Scholar in Forensic Science, India
}

*Corresponding author: Vinod Dhingra, Scholar in Forensic Science, India

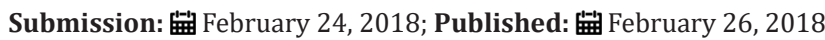

\section{Editorial}

The forensic toxicology laboratory generally performs analysis for toxic compounds in autopsy materials and related specimens to assist in the deaths by toxic substances. One of the unique aspects of postmortem toxicology work is that often specimens are received in various states of decomposition or putrefaction. Sometimes specimens denatured by heat or mummified all these samples create problems in analysis. For a variety of reasons, the volume of material available for analysis may be very limited. The problem faced by the forensic toxicologist during chemical analysis how to make the best use of the autopsy material.

In postmortem toxicology drug concentrations describe the role of drug in the death of person. During toxicological analysis various factors affects the quantity of drugs in autopsy materials like pharmacokinetic, pharmaco dynamics and clinical factors. Pharmacokinetics is an invaluable tool to help understand the time course of drug in the body.

In the majority of cases in clinical and forensic toxicological analysis, multi drug therapy and drug abuse is prevalent and this, together with the added problems of self medication with over the counter drugs along the wide spread use of alcohol, makes interpretation of drug quantity related data even more complicated.

The postmortem redistribution and occurs primarily by diffusion of drug from neighboring tissues, organs and stomach contents. This unequal distribution of drugs in tissues leads to changes in the blood concentration of drug after death.

Metabolism is an integral part of drug elimination as well as facilitating excretion of the drug, it may also affect the pharmacological response of a drug by altering its potency and/or duration of action with few exceptions, the metabolites of drugs and more polar than the parent drug and are therefore more likely to be excreted from the body. Most drugs are eliminated from the body by metabolism in the liver and/or by excretion of the drug and its metabolites by the kidneys other mechanism for drug metabolism and excretion also apply for some drugs and poisons. Drugs and metabolite are excreted mainly by the kidney in to urine. One of the major physiological factors that determine the variability in the rate of drug excretion into the urine is the $\mathrm{pH}$ of the urine [1-5].

Drugs with opposite pharmacological activities (e.g. barbiturates and amphetamines) may have an antagonistic effect; conversely, the additive effects or side effects of two drugs with the same pharmacological actions (e.g. control nervous system depressants) may prove fatal even though the individual drug concentrations are not toxic themselves. Further, a drug with a high affinity for tissue proteins might displace a second drug from binding sites, while a drug that changes urinary $\mathrm{pH}$ or that competes for the same active transport system in the proximal tubules of the kidney might inhibit renal excretion other important mechanism for drug interactions include interference with absorption of other drugs, modification of rates and routes of metabolism and changing the accessibility of receptors and tissue sites.

The change in the pharmacokinetics is an explanation of the increase sensitivity to drug effects in the elderly. For example, doses of benzodiazepines are reduced in the elderly to avoid excessive sedation and adverse effects on cognition. Diseases can affect all the processes by which a drug is absorbed, distributed and eliminated from the body. A drug may be absorbed poorly during gastrointestinal disturbances. Diseases like cardiovascular and others fundamentally affect distribution system metabolic and excretory pathways of drugs also alter their pharmacokinetics.

The enforcement agencies in drug related deaths generally asks the type of drug, their quantity, dose taken before death, route of administration, drug suitability in body, intention (suicidal, homicidal or accidental), time of dose taken which may be irrelevant for prosecution purpose some of these queries can be very well answered by panel of doctors. Apart from above for quantity of drugs following points must be taken into consideration i.e. quality of drugs, their constituents, were these given drug actually prescribed, some known allergy, were inject able given without bubble, were subject suffering from disease.

On the basis of above points for determination of quantity of drugs in autopsy material with reference to drug related deaths 
following information must be appropriately addressed about deceased at the time of analysis of autopsy material in forensic toxicology laboratory i.e. age, weight, sex, food taken, drug allergy, water intake, blood transfusions and blood loss, given antidotes, other drugs, doses of drug taken, vomits, motions, diseases, ailment of organs, bed head ticket, drug quality and their constituents, proper procedure utilization in delivering drugs, drug abuse habits and drug dependence etc. which will be helpful in finding quantity of drugs in autopsy material especially in drug related deaths [510].

\section{References}

1. Baselt RC (2002) Disposition of toxic drugs and chemicals in man. $\left(6^{\text {th }}\right.$ edn.), Chemical Toxicology Institute, Foster City, USA.

2. Curry AS (1988) Poison detection in human organs. ( $4^{\text {th }}$ edn.), Springfield, Charles C Thomas, USA.

3. Logan BK, Lindholm G (1996) Gastric contamination of postmortem blood samples during blind-stick sample collection. Am J Forensic Med Pathol 17: 109-111.

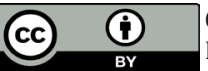

reative Commons Attribution 4.0

nternational License

For possible submission use the below is the URL
4. Baselt RH (2000) Disposition of toxic drugs and chemicals in man. (5 $5^{\text {th }}$ edn.), Chemical Toxicology Institute, Foster City, USA.

5. Levy H (2000) Metabolic drug interactions. Lippincott Williams \& Wilkins, London, England.

6. Olin BR (1990) Drug Interaction Facts. ( $2^{\text {nd }}$ edn), J B Lippincott, St Louis, USA.

7. Pacifici GM, Pelkone (2001) Inter individual variability in human drug metabolism: variability in drug metabolism, Taylor \& Francis, London, England.

8. Ritschel WA, Kearns GL (1999) Handbook of basic clinical pharmacokinetics, ( $5^{\text {th }}$ edn.), American Pharmaceutical Association, Washington, USA.

9. Williams JG, Aruoma OI (2000) Molecular drug metabolism and toxicology, OICA International, London, England.

10. Woolf TF (1999) Handbook of drug metabolism. In: Dekker (Ed.), New York, USA.

Your subsequent submission with Crimson Publishers will attain the below benefits

- High-level peer review and editorial services

- Freely accessible online immediately upon publication

- Authors retain the copyright to their work

- Licensing it under a Creative Commons license

- Visibility through different online platforms

- Global attainment for your research

- Article availability in different formats (Pdf, E-pub, Full Text)

- Endless customer service

- Reasonable Membership services

- Reprints availability upon request

- One step article tracking system 